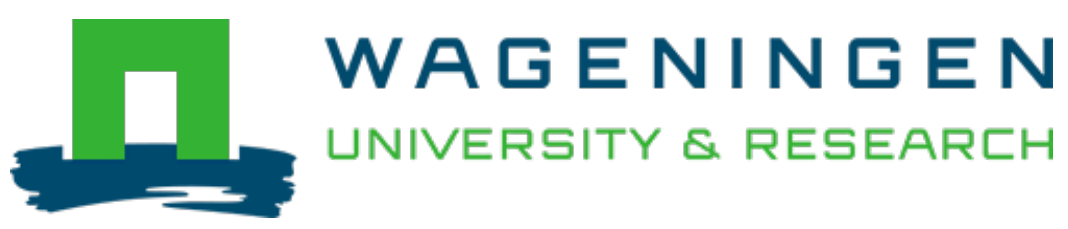

\title{
Using farmers' attitude and social pressures to design voluntary Bluetongue vaccination strategies
}

\author{
Preventive Veterinary Medicine \\ Sok, J.; Hogeveen, H.; Elbers, A.R.W.; Oude Lansink, A.G.J.M. \\ https://doi.org/10.1016/j.prevetmed.2016.09.016
}

This article is made publicly available in the institutional repository of Wageningen University and Research, under the terms of article $25 \mathrm{fa}$ of the Dutch Copyright Act, also known as the Amendment Taverne. This has been done with explicit consent by the author.

Article 25 fa states that the author of a short scientific work funded either wholly or partially by Dutch public funds is entitled to make that work publicly available for no consideration following a reasonable period of time after the work was first published, provided that clear reference is made to the source of the first publication of the work.

This publication is distributed under The Association of Universities in the Netherlands (VSNU) 'Article $25 \mathrm{fa}$ implementation' project. In this project research outputs of researchers employed by Dutch Universities that comply with the legal requirements of Article $25 \mathrm{fa}$ of the Dutch Copyright Act are distributed online and free of cost or other barriers in institutional repositories. Research outputs are distributed six months after their first online publication in the original published version and with proper attribution to the source of the original publication.

You are permitted to download and use the publication for personal purposes. All rights remain with the author(s) and / or copyright owner(s) of this work. Any use of the publication or parts of it other than authorised under article $25 \mathrm{fa}$ of the Dutch Copyright act is prohibited. Wageningen University \& Research and the author(s) of this publication shall not be held responsible or liable for any damages resulting from your (re)use of this publication.

For questions regarding the public availability of this article please contact openscience.library@,wur.nl 


\title{
Using farmers' attitude and social pressures to design voluntary Bluetongue vaccination strategies
}

\author{
J. Sok ${ }^{\mathrm{a}, *}$, H. Hogeveen ${ }^{\mathrm{a}}$, A.R.W. Elbers ${ }^{\mathrm{b}}$, A.G.J.M. Oude Lansink ${ }^{\mathrm{a}}$ \\ a Department of Social Sciences, Business Economics, Wageningen University, Hollandseweg 1, NL-6706 KN Wageningen, The Netherlands \\ ${ }^{\mathrm{b}}$ Department of Epidemiology, Crisis organisation and Diagnostics, Central Veterinary Institute (CVI) of Wageningen UR, P.O. Box 65, NL-8200 AB Lelystad, \\ The Netherlands
}

\section{A R T I C L E I N F O}

\section{Article history:}

Received 9 May 2016

Received in revised form 9 September 2016

Accepted 15 September 2016

JEL classification:

C39

$\mathrm{H} 50$

Q12

Q18

Keywords:

Farmers

Decision-making

Attitude

Social pressures

Disease control

Bluetongue

Voluntary vaccination

Policy instruments

\begin{abstract}
A B S T R A C T
Understanding the context and drivers of farmers' decision-making is critical to designing successful voluntary disease control interventions. This study uses a questionnaire based on the Reasoned Action Approach framework to assess the determinants of farmers' intention to participate in a hypothetical reactive vaccination scheme against Bluetongue.

Results suggest that farmers' attitude and social pressures best explained intention. A mix of policy instruments can be used in a complementary way to motivate voluntary vaccination based on the finding that participation is influenced by both internal and external motivation. Next to informational and incentive-based instruments, social pressures, which stem from different type of perceived norms, can spur farmers' vaccination behaviour and serve as catalysts in voluntary vaccination schemes.
\end{abstract}

(c) 2016 Elsevier B.V. All rights reserved.

\section{Introduction}

Bluetongue (BT) is a World Organization for Animal Health (OIE)-listed animal disease. An outbreak of an OIE listed disease has major implications for livestock production, policy and trade in the country or region affected (Burrell, 2002). All these impacts were experienced during the Bluetongue virus serotype 8 (BTV-8) epidemic from 2006 to 2009 in the Netherlands. The virus caused clinical disease in ruminants, thereby affecting dairy as well as other farm types in cattle, sheep and goat sectors (see Elbers et al. (2008) for an overview). Financial consequences of the epidemic in 2006 and 2007 in the Netherlands have been estimated around 200 million Euros, of which about 140 million Euros relating to the dairy cow sector (Velthuis et al., 2010).

\footnotetext{
* Corresponding author.

E-mail address: jaap.sok@wur.nl (J. Sok).
}

A reactive vaccination programme at transnational level was adopted in 2008 since the direct control measures and the ban of animal movements failed to stop the spread. The Dutch government offered farmers a vaccination scheme on the basis of voluntary participation with subsidy as a financial, incentive-based policy instrument. It fits in with a neoliberal governance style of cost and responsibility sharing (e.g. Maye et al., 2014) and is based on economic theory postulating that self-regulation may result in successful interventions at lower public cost (e.g. Oude Lansink, 2011). The ex-ante transaction costs of lobbying and legislation and ex-post transaction costs of surveillance and enforcement are minimized (Furubotn and Richter, 1998).

Since the implementation of the vaccination scheme, only a few Dutch farms got infected in 2008 and 2009. However, it is difficult to judge ex-post whether the voluntary approach was a success or a failure while many farms were already immunized via natural infection (Wilson and Mellor, 2009), which in combination with a low uptake could already be sufficient to control the spread. Actual 
uptake by dairy farmers have been estimated at 71\% in 2008 (with subsidy) (Elbers et al., 2010).

After the BTV-8 epidemic, Elbers et al. (2010), in an exploratory survey among Dutch farmers, showed that (1) prevention of production losses and (2) subsidization of vaccination were perceived as the main motives to vaccinate against BT. Other important motives mentioned were: (3) welfare concerns, (4) contribution to the eradication campaign and (5) recommendation by the practitioner.

To understand and predict individual vaccination decisions, rational choice models, i.e. expected utility theory (EUT) models are often applied (Hardaker and Lien, 2010; Rat-Aspert and Fourichon, 2010; Sok et al., 2014). In these models, the motives 1 and 2 are considered. It is often argued that governments should increase the expected utility (profits) by utilizing financial, incentive-based policy instruments to make voluntary disease control interventions effective.

Considering the motives 3-5 however, it might be that additional self-regulatory or motivational mechanisms exist that drive the decision to vaccinate, which cannot directly be inferred from rational choice models. Some of these mechanisms are embedded in different types of norms. Social psychological decision models emphasize the effect of social pressures on decisionmaking, such as the Reasoned Action Approach (RAA) (Fishbein and Ajzen, 2010). The RAA predicts that a given behaviour is determined by the strength of a person's intention to perform that behaviour. The intention is a function of three social-psychological constructs: attitude, perceived norms and perceived behavioural control. Nowadays different dimensions are captured within these constructs, also prompted through the use of multivariate statistical techniques (Thompson, 2004). Within attitude, an instrumental and experiential dimension are distinguished. Factors considered in a typical EUT model are similar to this instrumental dimension. Within perceived norm, an injunctive and descriptive dimension are distinguished. Within perceived behavioural control, a capacity and an autonomy dimension are distinguished (see Fishbein and Ajzen (2010) for an overview). In this study, only the construct of perceived norms is disentangled into an injunctive and descriptive dimension to investigate in more detail the social pressures operating on farmers.

Next to information and incentive-based instruments is the effectiveness of disease control interventions also dependent on reflecting, re-enforcing and shaping attitudes and norms within a community (Collier et al., 2010). Therefore an understanding of which of these constructs drive farmers' compliance with a policy intervention is critical for an efficient and effective design. The aim of this research is to assess which of the socio-psychological constructs and underlying dimensions drive farmers' intention to participate in a hypothetical reactive vaccination scheme against BT.

\section{Material and methods}

\subsection{Framework and statistical method}

The RAA model identifies the social-psychological constructs that may influence intention to carry out particular behaviours, so that statistical modelling can be used to estimate the nature and significance of these relationships.

The model can mathematically be represented as follows:

$B \sim I=f(A, P N, P B C)$,

where $P N=f\left(N_{I}, N_{D}\right)$,

$B$ given behaviour

I intention to perform the behaviour
$A$ attitude - the farmer's positive or negative evaluation of performing that behaviour

$P N$ perceived norms - the social pressures one feels to perform that behaviour

$N_{I}$ injunctive norm - the perceptions of what referents think he or she should do

$N_{D}$ descriptive norm - the perceived behaviour of others (farmers)

$P B C$ perceived behavioural control - the perceived own capability to perform that behaviour.

In this study, structural equation modelling (SEM) was used to estimate the entire RAA as a set of simultaneous equations. It models correlational and causal relationships among constructs and corrects for measurement errors of the observed variables that represent these constructs in the estimation procedure. A construct is a latent variable that can be defined in conceptual terms but cannot directly be measured or be measured without error. Therefore, a construct is represented by multiple variables that, in combination, give a reasonably accurate measure of the construct using factor analytic approaches (Hair et al., 2010).

The commonly applied two-step modelling approach in SEM, developed by Anderson and Gerbing (1988), was used. First step was to estimate a measurement model in which the variables were assigned to their constructs, using confirmatory factor analysis. Thus, based on the RAA model, it was a priori specified which variables make up which of the five constructs. Based on tests assessing the score reliability, score validity and overall model fit (e.g. see Fornell and Larcker, 1981), the measurement model was evaluated on its specification and consistency with the data. The second step was to estimate a structural model in which the causal relationships were tested to investigate the impact of the exogenous constructs attitude, injunctive norm, descriptive norm and perceived behavioural control on the endogenous construct intention. As constructs are often highly correlated, different model specifications were run to assess the presence of multicollinearity.

\subsection{Questionnaire and sample}

In Table 1 a description of the variables measured is given, with these elements being based on the standard questionnaire format provided by Fishbein and Ajzen (2010). In defining the action that respondents were to undertake (or rather, express their intention to undertake) Ajzen's TACT principle has been used, with actions defined in terms of target, action, context and time. For example, 'If Bluetongue (target) were to occur in the environment (context) this year (time), and a voluntary vaccination programme was to be announced (context), I am going to vaccinate my herd preventively (action). All questions were preceded with the phrase: "If Bluetongue were to occur in the environment this year", and for the questions related to the constructs perceived behavioural control and intention the words "and a voluntary vaccination programme was to be announced" were added to emphasize the voluntary nature of the vaccination scheme.

A 5-points semantic differential scale with five different bipolar adjective pairs (e.g. unsatisfying and satisfying) was used to measure attitude. The other variables were measured with 5-point bipolar Likert-type scales with endpoints "disagree” to 'agree'.

A random sample of 1500 Dutch dairy farms was drawn from the National Cattle Identification and Registration Database. The sample was restricted to farms with a herd size of at least 40 dairy cows, which is about 80 to $85 \%$ of the whole dairy farm population (LEI, 2016). These are more likely to be professional dairy farmers rather than hobby farmers. The latter type of farmers were excluded because it was felt that their decision-making process for vaccination decisions, in the face of a threat of a BT infection, could be made in a very different decision context (e.g. Gethmann et al., 2015). 
Table 1

Description of the variables for representing the constructs in the SEM.

\begin{tabular}{|c|c|c|}
\hline Construct and variable & & Description of the statement \\
\hline Attitude & $\begin{array}{l}a_{1} \\
a_{2} \\
a_{3} \\
a_{4} \\
a_{5}\end{array}$ & $\begin{array}{l}\ldots \text { unsatisfying - satisfying } \\
\ldots \text { disadvantageous }- \text { advantageous }^{\mathrm{b},{ }^{*}} \\
\ldots \text { necessary }- \text { unnecessary } \\
\ldots \text { unimportant }- \text { important }^{\mathrm{b}} \\
\ldots \text { acceptable - unacceptable } \\
\text { a,, }\end{array}$ \\
\hline Injunctive norm & $\begin{array}{l}n i_{1} \\
n i_{2} \\
n i_{3}\end{array}$ & $\begin{array}{l}\text { People who have something to do with my farm expect me to vaccinate my herd preventively. } \\
\text { People in the industry whose opinions I value would approve of me vaccinating my herd preventively. } \\
\text { People who are important to me think that I should vaccinate my herd preventively. }\end{array}$ \\
\hline Descriptive norm & $n d_{1}$ & Farmers like me are going to vaccinate their herd preventively. \\
\hline $\begin{array}{l}\text { Perceived (beh.) } \\
\text { control }\end{array}$ & $\begin{array}{l}p b c_{1} \\
p b c_{2} \\
p b c_{3}\end{array}$ & $\begin{array}{l}\text { I do have the possibility to vaccine my herd preventively. }{ }^{\mathrm{c}} \\
\text { I could vaccinate my herd preventively, if I wanted to. }{ }^{\mathrm{c}} \\
\text { It is up to me whether I vaccinate my herd preventively. }{ }^{\mathrm{d}}\end{array}$ \\
\hline Intention & $\begin{array}{l}i_{1} \\
i_{2} \\
i_{3}\end{array}$ & $\begin{array}{l}\text { I am going to vaccinate my herd preventively. } \\
\text { I do want to vaccinate my herd preventively. } \\
\text { I am willing to vaccinate my herd preventively. }\end{array}$ \\
\hline
\end{tabular}

a Experiential dimension.

b Instrumental dimension.

c Capacity dimension.

d Autonomy dimension.

* These variables were reversely recoded for the statistical analysis.

The questionnaire ${ }^{1}$ was pre-tested on two dairy farmers. The final, revised, questionnaire was sent out in January 2014, along with a pre-paid return envelope and an accompanying letter in which the relevance of the research was set out. Farmers were offered two possibilities to fill in the questionnaire: using the paper copy, or on-line. The letter ended with a guarantee of anonymity of responses and the offer of a financial incentive to take part: i.e. a $10 \%$ chance of winning a gift coupon of $€ 25$. After 4 weeks, a reminder was sent to all farmers in the sample. The final response, the 415 th, was returned March, resulting in a response rate of 28 percent. About one sixth of the returned questionnaires were filled out on-line. Observations with missing values were excluded from the statistical analysis, resulting in an effective sample size of 357.

\section{Results}

\subsection{Descriptive statistics}

Regarding respondents' attitude, mean rank scores of the observed variables $\left(a_{1}-a_{5}\right)$ indicated a fairly positive evaluation of the outcomes of the behaviour (3.57-3.86) (Table 2). Correlations among variables for attitude were high (all within-construct correlations are marked bold). Correlations between variables for attitude and intention were also high.

Regarding respondents' perceived norms, mean rank scores of the variables were around average (2.99-3.43). Correlations among variables for injunctive norm were high. The variable $n i_{2}$ based on the question "people in the industry whose opinion I value" had the highest mean rank but at the same time was only weakly correlated with the intention variables. The other two variables for injunctive norm correlated highly with those of intention, attitude and descriptive norm.

Regarding respondents perceived behavioural control, mean rank scores of the variables were just below or above 4 (3.95-4.18). The scores indicated that, on average, farmers were capable of performing vaccination against BT. The variable $p b c_{3}$, representing the autonomy dimension within perceived behavioural control, had the highest rank (4.18) but had modest correlations with the other

\footnotetext{
1 The questionnaire is available upon request.
}

variables within perceived behavioural control and at the same time was not correlated with all other variables, including those of intention.

Regarding respondents' intention, mean rank scores were slightly above average (3.11-3.43). The variable $i_{3}$ had the highest score (3.43), most likely because the phrase used - I'm willing to - was the least powerful expression to measure intention. Correlations among variables for intention were very high.

Correlations among observed variables for each construct were internally consistent given the $\alpha_{C}$ values (Table 2). The $\alpha_{C}$ for the constructs attitude and intention were "excellent", for injunctive norm "very good" and for perceived behavioural control "adequate" (Kline, 2011). For descriptive norm there was only one observed variable, hence the score reliability cannot be calculated for this construct.

\subsection{SEM estimations}

The evaluation of the measurement model resulted in a respecification. The main issue here was that the variable $p b c_{3}$ (representing the autonomy dimension) was removed from the model because of low score validity, and thus only the capacity dimension remained with perceived behavioural control.

Fig. 1 shows the estimated causal relationships, the extent to which the exogenous constructs attitude, injunctive norm, descriptive norm and perceived behavioural control impact upon the endogenous construct intention. All exogenous constructs inserted were allowed to correlate. The highest causal relationship was that of attitude on intention, while holding all other constructs constant. These results at first sight suggest that, for the vaccination behaviour, attitude is the main determinant of intention.

Given the discrepancy between beta's on and intercorrelations between constructs, results also suggested shared variance (multicollinearity) being present among exogenous constructs. Table 3 reports on different model specifications that were run to show where the multicollinearity was present. The main source of collinearity was found between the constructs attitude and injunctive norm when explaining intention. In model specifications $A$ and $B$, the beta's of both constructs were separately estimated, while in model specification $C$ they were jointly estimated. In the latter specification, the beta of injunctive norm got a much lower regression 
Table 2

Sample correlation matrix with means, standard deviations of the variables and Cronbach's alpha values of the constructs.

\begin{tabular}{|c|c|c|c|c|c|c|c|c|c|c|c|c|c|c|c|c|c|}
\hline Variable & & 1. & 2. & 3. & 4. & 5. & 6. & 7. & 8. & 9. & 10. & 11. & 12. & 13. & 14. & 15. & $\alpha_{C}$ \\
\hline 1. & $a_{1}$ & 1 & & & & & & & & & & & & & & & 0.90 \\
\hline 2. & $a_{2}$ & 0.72 & 1 & & & & & & & & & & & & & & \\
\hline 3. & $a_{3}$ & 0.67 & 0.59 & 1 & & & & & & & & & & & & & \\
\hline 4. & $a_{4}$ & 0.76 & 0.69 & 0.81 & 1 & & & & & & & & & & & & \\
\hline 5. & $a_{5}$ & 0.59 & 0.49 & 0.58 & 0.59 & 1 & & & & & & & & & & & \\
\hline 6. & $n i_{1}$ & 0.43 & 0.43 & 0.46 & 0.48 & 0.36 & 1 & & & & & & & & & & 0.80 \\
\hline 7. & $n i_{2}$ & 0.23 & 0.27 & 0.27 & 0.30 & 0.39 & 0.58 & 1 & & & & & & & & & \\
\hline 8. & $n i_{3}$ & 0.41 & 0.40 & 0.45 & 0.48 & 0.39 & 0.65 & 0.49 & 1 & & & & & & & & \\
\hline 9. & $n d_{1}$ & 0.30 & 0.26 & 0.21 & 0.28 & 0.25 & 0.44 & 0.26 & 0.33 & 1 & & & & & & & - \\
\hline 10. & $p b c_{1}$ & 0.24 & 0.27 & 0.21 & 0.29 & 0.35 & 0.20 & 0.29 & 0.19 & 0.04 & 1 & & & & & & 0.73 \\
\hline 11. & $p b c_{2}$ & 0.27 & 0.30 & 0.23 & 0.29 & 0.32 & 0.16 & 0.23 & 0.20 & 0.09 & 0.75 & 1 & & & & & \\
\hline 12. & $p b c_{3}$ & -0.08 & 0.00 & 0.00 & 0.00 & 0.04 & 0.00 & 0.01 & 0.00 & -0.05 & 0.35 & 0.31 & 1 & & & & \\
\hline 13. & $i_{1}$ & 0.66 & 0.56 & 0.58 & 0.68 & 0.51 & 0.50 & 0.26 & 0.51 & 0.35 & 0.29 & 0.28 & 0.02 & 1 & & & 0.94 \\
\hline 14. & $i_{2}$ & 0.64 & 0.54 & 0.58 & 0.65 & 0.51 & 0.51 & 0.28 & 0.50 & 0.35 & 0.30 & 0.30 & 0.03 & 0.92 & 1 & & \\
\hline 15. & $i_{3}$ & 0.60 & 0.54 & 0.57 & 0.61 & 0.58 & 0.45 & 0.32 & 0.48 & 0.31 & 0.31 & 0.31 & 0.02 & 0.81 & 0.81 & 1 & \\
\hline Mean & & 3.64 & 3.57 & 3.57 & 3.75 & 3.86 & 2.99 & 3.43 & 3.03 & 3.27 & 3.95 & 4.08 & 4.18 & 3.22 & 3.11 & 3.43 & \\
\hline Std. Error & & 1.13 & 1.02 & 1.12 & 1.08 & 1.06 & 1.24 & 1.16 & 1.18 & 1.00 & 0.99 & 0.95 & 1.04 & 1.26 & 1.24 & 1.22 & \\
\hline
\end{tabular}

Within-construct correlations are marked bold.

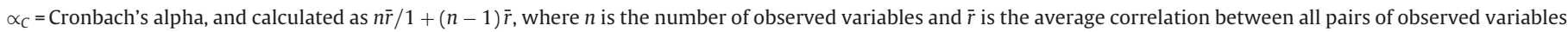
for one construct.

Table 3

Different structural model specifications to show the presence of multicollinearity among constructs.

\begin{tabular}{|c|c|c|c|c|c|c|}
\hline \multirow[t]{2}{*}{ Model spec. } & \multirow[t]{2}{*}{ Exogenous constructs inserted } & \multicolumn{4}{|c|}{ Beta estimates of: } & \multirow[t]{2}{*}{$\mathrm{R}^{2}$} \\
\hline & & 1. Attitude & $\begin{array}{l}\text { 2. Injunctive } \\
\text { norm }\end{array}$ & $\begin{array}{l}\text { 3. Descriptive } \\
\text { norm }\end{array}$ & $\begin{array}{l}\text { 4. Perceived } \\
\text { beh. control }\end{array}$ & \\
\hline A & 1. & 0.77 & & & & 0.59 \\
\hline B & 2. & & 0.61 & & & 0.37 \\
\hline $\mathrm{C}$ & 1. and 2 . & 0.62 & 0.23 & & & 0.62 \\
\hline $\mathrm{D}$ & 3. & & & 0.38 & & 0.14 \\
\hline E & 2. and 3. & & 0.56 & 0.10 & & 0.37 \\
\hline $\mathrm{F}$ & 4. & & & & 0.37 & 0.13 \\
\hline G & 1., 2., 3. and 4 . & 0.61 & 0.18 & 0.09 & 0.08 & 0.65 \\
\hline
\end{tabular}

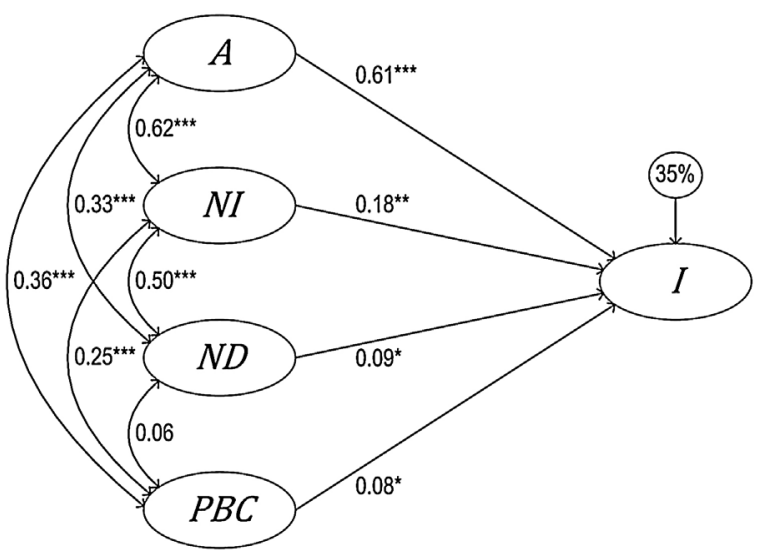

Fig. 1. Structural model estimation, where an ellipse represents a construct, a circle an error term, a straight arrow a dependence relationship and a curved arrow a correlational relationship. The number of asterisks denote the significance level where ${ }^{* * *},{ }^{* *}$ and ${ }^{*}$ are at 0.001 (highly), 0.01 (moderately) and 0.10 (somewhat) respectively.

weight due to the high correlation with attitude. Therefore, in addition to attitude, injunctive norm was an important determinant of intention.

A smaller source of collinearity was found between both normative constructs when explaining intention. In model specifications B and $D$, the beta's of both normative constructs were separately estimated, while in model specification E they were jointly estimated.
In the latter specification, the beta of descriptive norm got a much lower regression weight due to the high correlation with injunctive norm. Therefore, in addition to injunctive norm also descriptive norm had some impact upon intention. Or put differently, within the perceived norm construct, injunctive norm was more important than descriptive norm.

\section{Discussion}

Results of this study suggest that attitudinal considerations outweigh normative and control considerations as causal factors influencing intention to vaccinate against BT. Thus, farmers who exhibited a positive intention to vaccinate evaluated that behaviour positively, and vice versa. Although attitude turned out to be the main determinant of intention, results indicated that social pressures influenced intention formation as well.

Three main types of policy instruments are commonly distinguished: financial, incentive-based (carrots), regulative (sticks), and informational (promises or sermons) instruments (Rothschild, 1999; Bemelmans-Videc et al., 2011). Traditionally, the focus has been on financial and regulative instruments (Collier et al., 2010). The first and third type of policy instrument can be used to motivate voluntary participation where carrots are 'external motivators' and promises 'internal motivators'. Both these instruments were used in the past BT vaccination strategy in 2008 (Ministry of Economic Affairs, 2008).

Since attitude is the main determinant of intention and farmers, on average, expressed a fairly positive evaluation of the outcomes of the behaviour, an obvious type of policy instrument to stimu- 
late the vaccination uptake are informational instruments that can increase the internal motivation by reasoned opinions. One should consider that information is more likely accepted if there is a credible communicator, a high level of 'similarity' between the audience and communicator and both the message and communicator must be perceived as trustworthy (Petty and Cacioppo, 1996).

Subsidization as a financial, incentive-based instrument, is an external motivator to encourage participation by making herd vaccination cheaper. Its effect on farmers' vaccination behaviour can be heterogeneous as different crowding effects can occur. Subsidization can strengthen (crowding-in) but also weaken (crowding-out) the internal motivation (Frey, 1993; Deci et al., 1999) and norms that induce behaviour externally (Bowles and Polanía-Reyes, 2012; Kuhfuss et al., 2015). It is important to take into account that different groups of farmers base their participation decisions on different considerations, and therefore a mix of instruments is required to maximize the uptake (Barnes et al., 2015).

The model of individual decision-making utilized in this paper originates from social psychology and is not a rational choice model. The RAA gives more weight to social aspects of decision-making.

Results show that, for the BT vaccination decision problem, farmers' decision-making is affected by social pressures. Thus, farmers in this respect do not act as autonomous actors who can be encouraged to participate only by providing information or incentives, but they are influenced by what referents think (injunctive norm) and what the expected behaviour of other farmers will be (descriptive norm).

Given that these social interactions among farmers and other referents about vaccination decisions exist, motivational mechanisms, such as peer group pressure, can be actively used as a fourth type of policy instrument to motivate participation (Leeuwis, 2007; Collier et al., 2010). Social pressures might take the role of a 'catalyst' among the mix of policy instruments used in BT vaccination strategies based on voluntary participation, and leverage the (cost)effectiveness and efficiency of such interventions.

Intervention design can be further supported by empirically analyzing the indirect measures, i.e. looking at which underlying beliefs explain each construct (Sok et al., 2015). Studying indirect measures is very relevant as they can help understanding what exactly drives the behaviour (Montaño and Kasprzyk, 2008). Attitudinal and normative beliefs are of most interest since this analysis showed that the behaviour is driven by attitudinal considerations and injunctive and to a lesser extent descriptive norms. Moreover, the heterogeneity in farmers' beliefs can be mapped out with behavioural concepts, such as perceived risk and personality traits, and with differences in farming structures (Sok et al., 2016).

In conclusion, it has been shown that farmers' attitude and social pressures best explained intention to vaccinate against BT. Informational policy instruments are used for motivating farmers' whose attitude is favourable; they can be motivated internally by reasoned opinions. Incentive-based policy instruments are used for motivating farmers externally by financial compensation. The effect of these subsidies on vaccination behaviour is likely heterogeneous and for each farmer not necessarily positive. Next to informational and incentive-based instruments, social pressures, which stem from different type of perceived norms, can spur farmers' vaccination behaviour and serve as catalysts in voluntary vaccination schemes.

\section{Acknowledgments}

This research was funded by the Ministry of Economic Affairs (Netherlands Food and Consumer Products Safety Authority) of the Netherlands via EMIDA ERA-NET "Coordination of European Research on Emerging and Major Infectious Diseases of Livestock" (funded by the European Commission's Seventh Framework Programme, Project No. 219235).

The authors would like to thank Ivo van der Lans for his valuable input to the statistical analysis, Philip Jones for his valuable comments to the manuscript and three anonymous reviewers for their comments.

\section{References}

Anderson, J.C., Gerbing, D.W., 1988. Structural equation modeling in practice: review and recommended two-step approach. Psychol. Bull. 103, 411-423.

Barnes, A.P., Moxey, A.P., Vosough Ahmadi, B., Borthwick, F.A., 2015. The effect of animal health compensation on 'positive' behaviours towards exotic disease reporting and implementing biosecurity: a review, a synthesis and a research agenda. Prev. Vet. Med. 122, 42-52.

Bemelmans-Videc, M.-L., Rist, R.C., Vedung, E.O., 2011. Carrots, Sticks, and Sermons: Policy Instruments and Their Evaluation. Transaction Publishers.

Bowles, S., Polanía-Reyes, S., 2012. Economic incentives and social preferences: substitutes or complements? J. Econ. Lit. 50, 368-425.

Burrell, A., 2002. Animal disease epidemics implications for production, policy and trade. Outlook Agric. 31, 151-160.

Collier, A., Cotteril, A., Everett, T., Muckme, R., Pike, T., Vanstone, A., 2010. Understanding and influencing behaviours: a review of social research, economics and policymaking. Defra Discussion Paper.

Deci, E.L., Koestner, R., Ryan, R.M., 1999. A meta-analytic review of experiments examining the effects of extrinsic rewards on intrinsic motivation. Psychol. Bull. 125, 627-668.

Elbers, A.R., Backx, A., Meroc, E., Gerbier, G., Staubach, C., Hendrickx, G., van der Spek, A., Mintiens, K., 2008. Field observations during the bluetongue serotype 8 epidemic in 2006. I. Detection of first outbreaks and clinical signs in sheep and cattle in Belgium, France and the Netherlands. Prev. Vet. Med. 87, 21-30.

Elbers, A.R., de Koeijer, A.A., Scolamacchia, F., van Rijn, P.A., 2010. Questionnaire survey about the motives of commercial livestock farmers and hobby holders to vaccinate their animals against Bluetongue virus serotype 8 in 2008-2009 in the Netherlands. Vaccine 28, 2473-2481.

Fishbein, M., Ajzen, I., 2010. Predicting and Changing Behavior: The Reasoned Action Approach. Psychology Press, New York.

Fornell, C., Larcker, D.F., 1981. Evaluating structural equation models with unobservable variables and measurement error. J. Mark. Res. 18, 39-50.

Frey, B.S., 1993. Motivation as a limit to pricing. J. Econ. Psychol. 14, 635-664.

Furubotn, E.G., Richter, R., 1998. Institutions and Economic Theory: The Contribution of the New Institutional Economics. The University of Michigan Press, Ann Arbor.

Gethmann, J., Zilow, V., Probst, C., Elbers, A.R.W., Conraths, F.J., 2015. Why German farmers have their animals vaccinated against Bluetongue virus serotype 8: results: of a questionnaire survey. Vaccine 33, 214-221.

Hair, J.F., Black, W.C., Babin, B.J., Anderson, R.E., 2010. Multivariate Data Analysis, Seventh Edition. Prentice Hall Englewood Cliffs, NJ.

Hardaker, J.B., Lien, G., 2010. Probabilities for decision analysis in agriculture and rural resource economics: the need for a paradigm change. Agric. Syst. 103, 345-350.

Kline, R.B., 2011. Principles and Practice of Structural Equation Modeling, 3rd ed. The Guilford Press, New York.

Kuhfuss, L., Préget, R., Thoyer, S., Hanley, N., 2015. Nudging farmers to enrol land into agri-environmental schemes: the role of a collective bonus. Eur. Rev. Agric. Econ. 43 (4), 609-636.

LEI, 2016. BINternet (Farm Accountancy Data Network). Available at: http://www. agrimatie.nl/binternet.aspx?ID=7\&bedrijfstype=2.

Leeuwis, C., 2007. The Role of Communicative Intervention in Policy Planning: Instrumental and Interactive Approaches Communication for Rural Innovation. Blackwell Science Ltd., pp. 49-58.

Maye, D., Enticott, G., Naylor, R., Ilbery, B., Kirwan, J., 2014. Animal disease and narratives of nature: farmers' reactions to the neoliberal governance of bovine tuberculosis. J. Rural Stud. 36, 401-410.

Ministry of Economic Affairs, 2008. Vaccinatieplan Blauwtong (in Dutch). Available at: http://www.rijksoverheid.nl/documenten-en-publicaties/rapporten/2008/ 04/24/vaccinatieplan-blauwtong.htm.

Montaño, D.E., Kasprzyk, D., 2008. Theory of reasoned action, theory of planned behavior, and the integrated behavioral model. In: Glanz, K., Rimer, B.K., Viswanath, K. (Eds.), Health Behavior and Health Education: Theory, Research, and Practice., 4th ed. Jossey-Bass, San Francisco (Chapter 4.

Oude Lansink, A.G.J.M., 2011. Public and private roles in plant health management. Food Policy 36, 166-170.

Petty, R.E., Cacioppo, J.T., 1996. Attitudes and Persuasion: Classic and Contemporary Approaches. Westview Press.

Rat-Aspert, O., Fourichon, C., 2010. Modelling collective effectiveness of voluntary vaccination with and without incentives. Prev. Vet. Med. 93, 265-275.

Rothschild, M.L., 1999. Carrots, sticks, and promises: a conceptual framework for the management of public health and social issue behaviors. J. Mark. 63, 24-37.

Sok, J., Hogeveen, H., Elbers, A.R.W., Velthuis, A.G.J., Oude Lansink, A.G.J.M., 2014. Expected utility of voluntary vaccination in the middle of an emergent 
Bluetongue virus serotype 8 epidemic: a decision analysis parameterized for Dutch circumstances. Prev. Vet. Med. 115, 75-87.

Sok, J., Hogeveen, H., Elbers, A.R.W., Oude Lansink, A.G.J.M., 2015. Farmers' beliefs and voluntary vaccination schemes: bluetongue in Dutch dairy cattle. Food Policy 57, 40-49.

Sok, J., Hogeveen, H., Elbers, A.R.W., Oude Lansink, A.G.J.M., 2016. Perceived risk and personality traits explaining heterogeneity in Dutch dairy farmers' beliefs about vaccination against Bluetongue. J. Risk Res., 1-17.
Thompson, B., 2004. Exploratory and confirmatory factor analysis. American Psychological Association, Washington, DC.

Velthuis, A.G., Saatkamp, H.W., Mourits, M.C., de Koeijer, A.A., Elbers, A.R., 2010 Financial consequences of the Dutch bluetongue serotype 8 epidemics of 2006 and 2007. Prev. Vet. Med. 93, 294-304

Wilson, A.J., Mellor, P.S., 2009. Bluetongue in Europe: past, present and future. Philos. Trans R. Soc. Lond. B: Biol. Sci. 364, 2669-2681. 